\title{
Energy renovation of listed buildings
}

\author{
Bjerregaard Jensen, Lotte; Nielsen, Martin Vraa
}

\section{Published in:}

Proceedings of ISES Solar World Congress 2011

Publication date:

2011

Link back to DTU Orbit

Citation (APA):

Bjerregaard Jensen, L., \& Nielsen, M. V. (2011). Energy renovation of listed buildings. In Proceedings of ISES Solar World Congress 2011

\section{General rights}

Copyright and moral rights for the publications made accessible in the public portal are retained by the authors and/or other copyright owners and it is a condition of accessing publications that users recognise and abide by the legal requirements associated with these rights.

- Users may download and print one copy of any publication from the public portal for the purpose of private study or research.

- You may not further distribute the material or use it for any profit-making activity or commercial gain

- You may freely distribute the URL identifying the publication in the public portal

If you believe that this document breaches copyright please contact us providing details, and we will remove access to the work immediately and investigate your claim. 


\title{
ENERGY RENOVATION OF LISTED BUILDINGS
}

\author{
L.B. Jensen ${ }^{1}$, M. V. Nielsen ${ }^{2}$ \\ ${ }^{1}$ Technical University of Denmark, Lyngby (Denmark) \\ ${ }^{2}$ Technical University of Denmark, Lyngby (Denmark)
}

\section{Introduction}

Energy renovation often includes adding an insulating layer to the building envelope either on the exterior or the interior. The positive effect of this is well documented, and in many cases reducing the heat loss by a better insulating and tighter building envelope is a reasonable solution. However, the design scope of energy renovation should be constantly challenged in order to attract the interest of investors, architects, designers and, last but not least, local authorities involved with the preservation of cultural heritage in our cities. When renovating any built environment, subjective factors such as aesthetics and spatial quality should be included to provide robust solutions that achieve more than just a reduction in heat loss.

Recladding of façades can have qualitative drawbacks for the architectural expression when placed on the exterior where the patina and history of e.g. a brickwork façade is lost. Insulation placed in the interior of the façade can cause moisture accumulation and the build-up of mould (Byg-Erfa \# 310910 29). Insulating the interior of the façade also prevents the insulation of connections between the floor structure and the façade, thus allowing thermal bridges. The most important drawback with interior insulation is that it consumes often extremely valuable square metres. It should be noted that in recent years new insulation products based on capillary and diffusion-open materials that distribute moisture to the surface and air in the building have reached the market. The moisture, however, must be removed from the air by means of increased mechanical ventilation, which also demands extra energy.

Furthermore, whether on the exterior and the interior of the façade, insulation can result in an increased risk of overheating problems, the potential scale of which is often neglected in historical buildings. It is important to take the indoor climate quality into account and not just look at the energy balance of the building. Since the basic geometry of these existing buildings will not change, it could be a good idea to start the design process with an advanced simulation that would normally be made later in the process.

The design strategies are presented using residential buildings built between 1870 and 1950 . The walls are traditional loadbearing, and consist of exposed brickwork. All the cases have architectural qualities worth preserving.

In the presentation of the cases, we only consider the effect on energy demand and the number of overheating hours. Cost, payback time, LCA, extended indoor climate analysis, etc. are not considered. The cases are not directly comparable. The aim of this paper is to use the cases to present alternative design strategies and expand the scope of solutions for energy renovation of listed buildings. The case studies were initially carried out using the professional simulation software thought most adequate for the requirements by students of the department of civil engineering at the Technical University of Denmark; Nikolaj Noerregaard Rasmussen, Morten Rung (REPO) Rene Bukholt, Mads Rasmussen (Case 1) and Stine Rolle (Case 2).

\section{Case 1: Beneficial use of passive solar heat gain}

Public housing projects from the 1950s in Denmark have high architectural quality. But the energy consumption and out-dated spatial organization of the flats call for renovation to achieve a better mix of employed and unemployed occupants. The construction is loadbearing massive brick walls. The floor structure is made of in situ-cast reinforced concrete with a wooden cladding.

The design strategy for this case was based on quite substantial simulations of the existing building's indoor climate in a representative flat carried out at the beginning of the design process. 

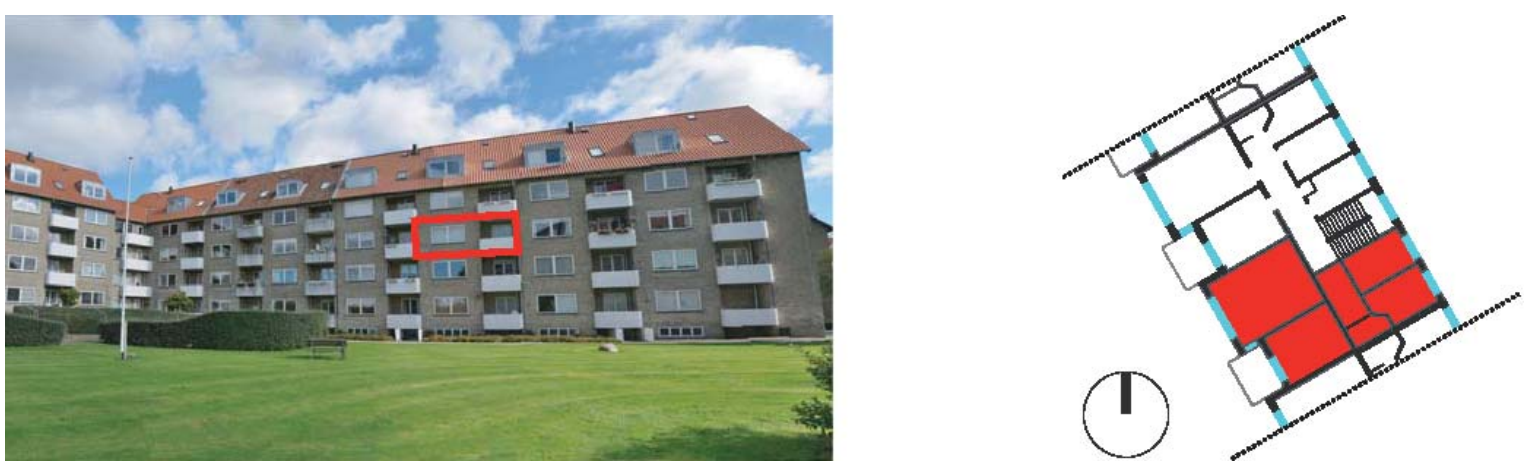

Fig. 1: The representative flat marked on the existing south-west façade (left) and in plan (right)

The energy demand was simulated using the calculation method prescribed in the Danish Building Regulations (EBST, 2010), while the simulation of the indoor thermal environment was carried out in the more detailed program BSim (BSIM, 2006). The BSim simulation model was divided into two segments: a north-east-facing and a south-east-facing, to evaluate the risk of overheating due to orientation. The number of hours above $27^{\circ} \mathrm{C}$ allowed was compared to Danish standards for offices because there are currently no guidelines for evaluating overheating problems in domestic settings. The guideline threshold value for when an office environment can be considered as having overheating problems is 25 hours above $27^{\circ} \mathrm{C}$ (REF: DS 474).

\subsection{Current situation}

The energy simulation of the flat's current construction shows an energy demand of $116.7 \mathrm{kWh} / \mathrm{m}^{2} /$ year. The heating demand of $94.2 \mathrm{kWh} / \mathrm{m}^{2} /$ year constitutes the majority of the total energy demand, while the electricity demand (for ventilation fans and pumps) is $7.7 \mathrm{kWh} / \mathrm{m}^{2} /$ year and the energy demand for domestic hot water $\left(250 \mathrm{l} / \mathrm{m}^{2} /\right.$ year) is $14.8 \mathrm{kWh} / \mathrm{m}^{2} /$ year. (fig. 4)

The simulation of the building's current indoor thermal environment shows potential overheating problems, particularly for south-facing rooms, with a considerable number of hours where the temperature exceeds $27^{\circ} \mathrm{C}$. Hours above $27^{\circ} \mathrm{C}$ total 27 for the north-east-facing and 101 for the south-west-facing zone. (fig.5)

\subsection{Renovation solutions}

Based on the simulations of the current building's energy demand and indoor thermal environment, three renovation solutions aimed at reducing energy demand and overheating problems are proposed and analysed:

1. External insulation on the north-east-facing façade

2. External insulation on the north-east-facing façade and internal insulation on the south-west-facing façade

3. External insulation on the north-east-facing façade, no interior insulation on the south-west-facing façade, but increased potential for passive solar heating.

The variations were chosen in order to investigate the possibility of replacing interior insulation by improved access for solar heating. Due to a wish to preserve the architectural expression facing the park and the technical difficulties posed by the extruding balconies, exterior insulation of the south-west-facing façade was not considered an option. Exterior insulation was, however, considered possible for the less expressive north-east-facing façade. Furthermore, another difference between the north-east and south-west-facing façades was in the potential for passive solar heat gain.

To establish the increased potential for passive solar heating, the south-west-facing window area in the living room is increased in the simulation from $3.78 \mathrm{~m}^{2}$ to $5.67 \mathrm{~m}^{2}$ by replacing the existing opaque brick parapet with window. As mentioned earlier, the simulation of the indoor thermal environment made early in the design process, showed excessive numbers of hours with temperatures above $27^{\circ} \mathrm{C}$. Thus, a more beneficial utilization of the passive solar heat gain to reduce heating demand during the winter season would simultaneously have to include remedies to reduce solar heat gain during the summer season. Therefore, a 
solution combining fixed and dynamic solar shading was proposed.

The fixed solar shading was designed using an application in Ecotect (REF for Ecotect) that depicts where direct sunlight meets a model of a sunshade. This made it possible to minimize the surface area and thereby optimize daylight intake while affecting the architectural expression the least.(fig.2)
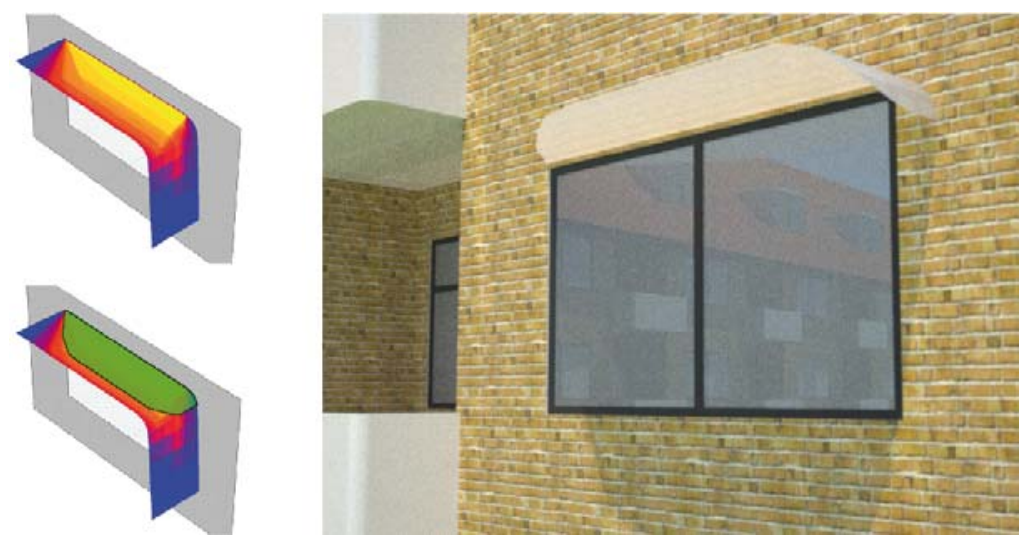

Fig. 2: Illustration of the design of the fixed solar shading showing insolation intensity and minimization of surface area (left) and the final geometry added to the existing façade (right)

The dynamic solar shading, which could be perceived as a dynamic parapet, was added to further reduce the number of hours with temperatures over $27^{\circ} \mathrm{C}$. The reasoning behind shading the window from below is that an area at the top of the window can be maintained for view to the outside, and the top is already shaded by the fixed solar shading.(fig.3)
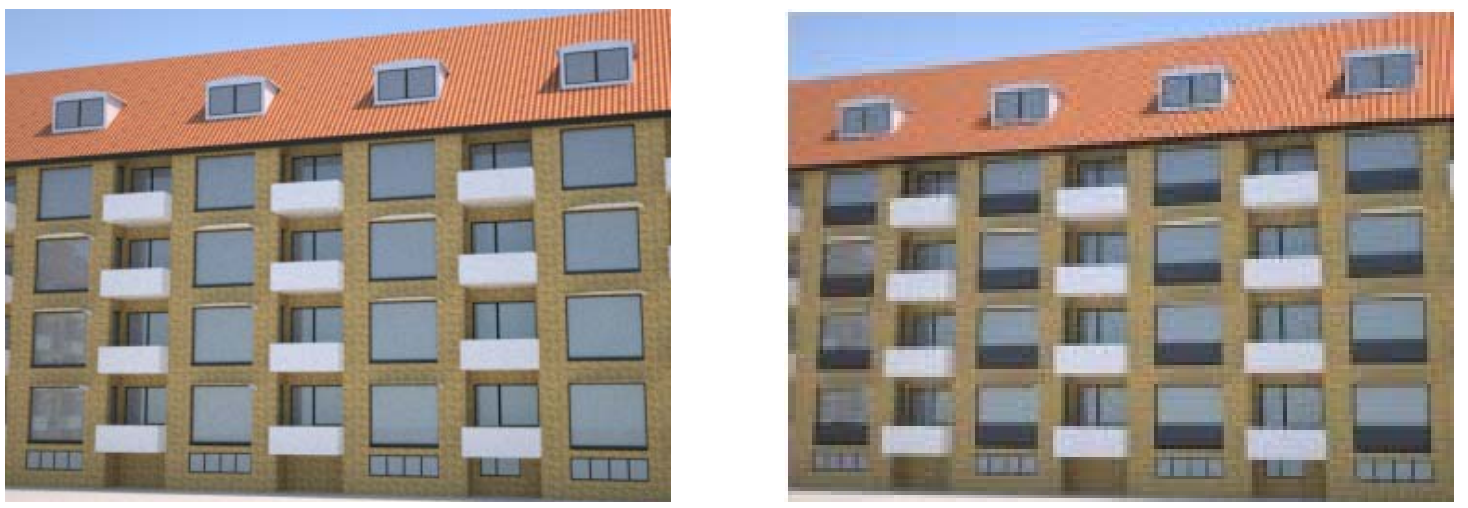

Fig. 3: Illustration of renovation solution 3 with increased window area and the dynamic parapet inactive (left) and active (right)

The parameter variation with and without interior insulation shows a general decrease in heating demand when the insulation of the façades is increased. Adding external insulation to the north-eastern façade, as proposed in Solution 1, reduces the heating demand by 35\%. Adding insulation to both north-eastern and south-western façades reduces the heating demand by $46 \%$ as proposed in solution 2 .

Combining increased insulation on the north-eastern façade with an increased window area and solar shading as proposed in Solution 3 reduces the heating demand by 39\% compared to the existing situation.

Electricity demand and energy demand for domestic hot water is constant for all simulated models because the mechanical ventilation rate, pump operation and use of domestic hot water are assumed constant. (fig.4) 


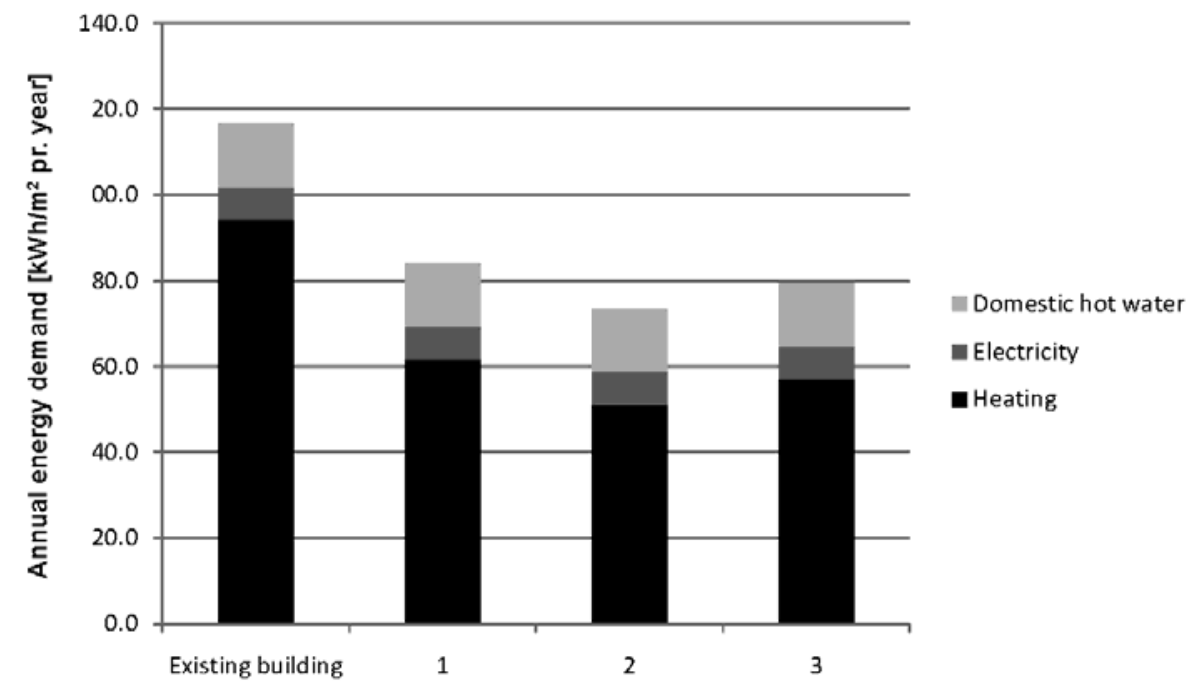

Fig. 4: Annual energy demand simulated in accordance with Danish standards for the existing building and for Solutions 1-3)

The number of hours with an indoor temperature exceeding $27^{\circ} \mathrm{C}$ decreases when external insulation is added to the north-east-facing façade (Solution 1) by $81 \%$ for the north-eastern and by $24 \%$ for the southwestern zone. On the other hand, overheating increases by $40 \%$ for the south-western zone compared to the existing situation, when interior insulation is also added to the south-west-facing façade (Solution 2). The difference between Solutions 1 and 2 has little effect on overheating problems in the north-eastern zone.

The potential for a more beneficial utilization of the available passive solar heat gain combined with effective solar shading, as proposed in Solution 3, results in a decrease in the number of hours where the indoor temperature exceeds $27^{\circ} \mathrm{C}$ by $81 \%$ for the north-eastern and by $20 \%$ for the south-western zone, showing similar reductions to Solution 1. (Fig.5)

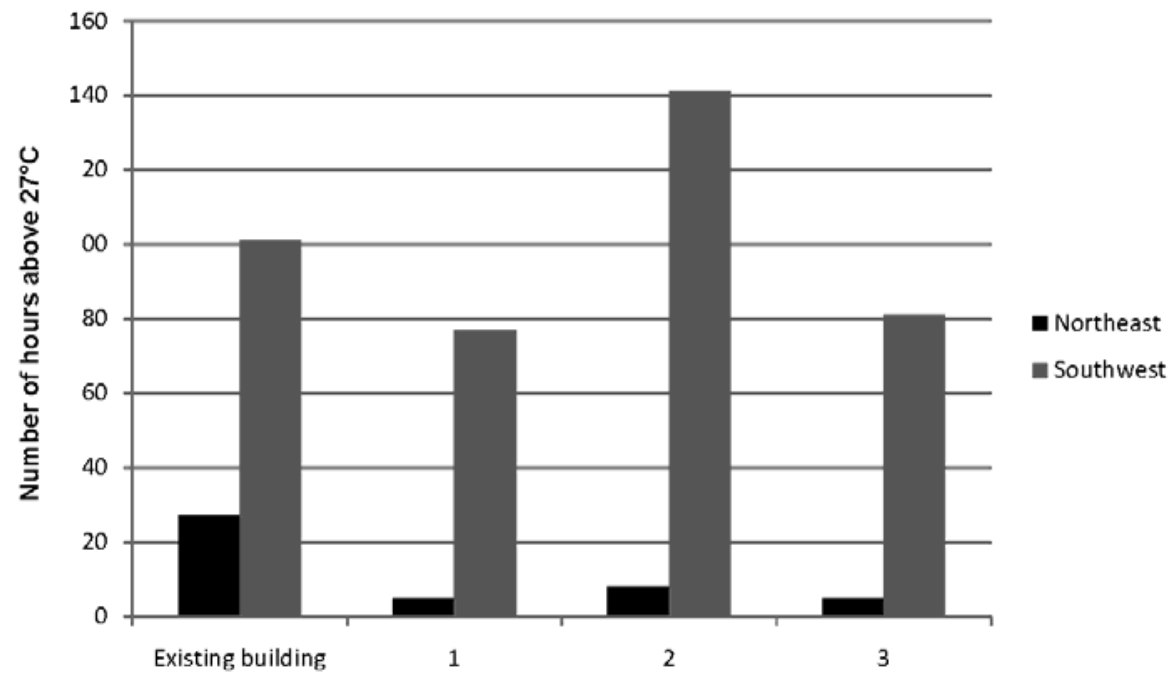

Fig. 5: The annual number of hours with indoor temperatures exceeding $27^{\circ} \mathrm{C}$ simulated in BSim for the existing building and for Solutions 1-3

The general tendency for increased numbers of hours with indoor temperatures exceeding $27^{\circ} \mathrm{C}$ when adding insulation to the opaque parts of the building envelope seems to be partially caused by the decrease in Uvalue, and partially by the reduced utilization of the thermal mass. The increased insulation value reduces heat transmission not only during winter, but also during summer, which results in an accumulation of heat and subsequently overheating. Furthermore, the additional internal insulation dramatically reduces the heat 
exchange between the internal environment and the thermal mass represented in the massive brick façade with a high heat capacity. This makes it impossible to use the potential beneficial cooling energy stored in the brick façade as a result of the lower temperatures during the night. Solution 3, however, combines the passive heat gain that is possible to obtain from the south-west with the reduction in heat loss from the northeast, where the amount of solar radiation is low, while maintaining the thermal storage capacity in the masonry walls.

\subsection{Conclusion}

A careful design process informed by advanced energy and indoor climate simulations from the start can lead to proposals with a combination of larger windows and shading which will increase the daylight level and increase the passive solar heat potential in the thermal mass of the structure. A more precise placement of insulation at the most efficient locations, instead of a full cover wrapping, combined with the abovedescribed alternatives, leaves more space for creativity in energy renovation. Thus, Solution 3 represents a relevant alternative to traditional insulation by being able to obtain the desired equilibrium between energy reduction and improved thermal indoor environment.

It could be concluded that - even in buildings which have potential problems with overheating - passive solar heating in combination with dynamic and fixed solar shading could be an alternative to interior insulation. However, a solution based on passive solar heating risks changing the architectural expression and structure of the building dramatically and in the case of some listed buildings would therefore not pose an alternative to interior insulation of the façades.

\section{Case 2: Energy production as an alternative}
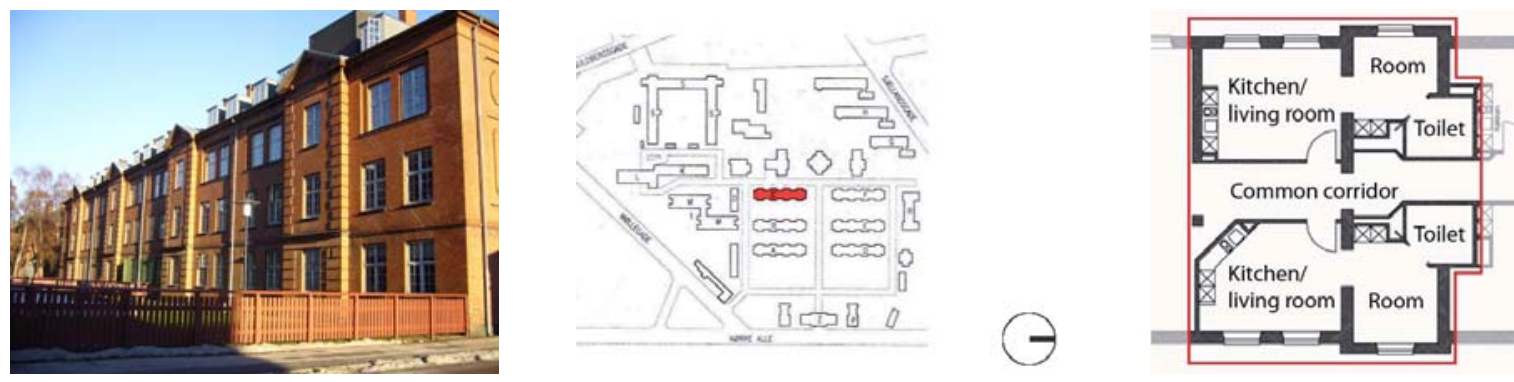

Fig. 6: Picture of the building used in Case 2 (left) Illustration of the building context (left) and the representative section used for simulations (right).

The case is a listed building, originally designed as a hospital and erected between 1890 and 1900 but converted to small independent flats for retired people in the 1990s. The area consists of several narrow three-storey buildings oriented east-west with windowless gables facing south and north (fig. 6). The construction is massive, load bearing masonry walls. In the reference building, the walls, roof and windows are unaltered, but a new ventilation system with heat recovery was added in 1990 .

As in the previous case, extensive and detailed simulations of the indoor climate, energy balance and energy demand formed the starting point for the design process. In this case, the simulations were made in IES Virtual Environment (CIBSE, 1999). The simulations were of a representative section containing two apartments - one facing east and the other facing west with a common corridor between. The simulation model was built up so that each room was represented by a thermal zone.(fig. 6)

\subsection{Current Situation}

The energy simulation of the current construction displayed in Fig. 7 shows an energy demand of 110.1 $\mathrm{kWh} / \mathrm{m}^{2} /$ year. The heating demand of $72 \mathrm{kWh} / \mathrm{m}^{2} /$ year constitutes the majority of the total energy demand, while the electricity demand for ventilation is $10.6 \mathrm{kWh} / \mathrm{m}^{2} /$ year and the energy demand for domestic hot water (523 $\mathrm{l} / \mathrm{m}^{2} /$ year) is $27.5 \mathrm{kWh} / \mathrm{m}^{2} /$ year.

The detailed simulation of the current building's indoor thermal environment shows no critical problems 
with overheating. The number of hours where the indoor temperature exceeds $26^{\circ} \mathrm{C}$ varies between 33 and 0.(fig.8)

Furthermore, simulations of the representative section show that the narrow building and relatively large windows result in apartments with ample daylight.

\subsection{Renovation solutions}

As mentioned earlier the building is listed, which means that the exterior expression of the building cannot be altered. Therefore renovation solutions include interior insulation of the building envelope, replacement of existing windows with more energy-efficient ones, and especially the potential for producing electricity with solar cells and using solar panels for heating and domestic water. The aim was to investigate whether the reduction in heat loss achievable with interior insulation of the building façades could be compensated for by an equivalent production of energy, thus posing a design alternative. Three renovation solutions where simulated and analysed:

1. insulation of attic and replacement of windows

2. insulation of attic, replacement of windows and interior insulation of façades

3. insulation of attic, replacement of windows and production of energy

Simulations of the annual energy demand and the indoor thermal environment for renovation solutions 1 and 2 show a decrease in heating demand and an increase in the number of hours where the indoor temperature exceeds $26^{\circ} \mathrm{C}$. Heating demand decreases by $34 \%$ with Solution 1 and by $70 \%$ with Solution 2 compared to the existing situation.

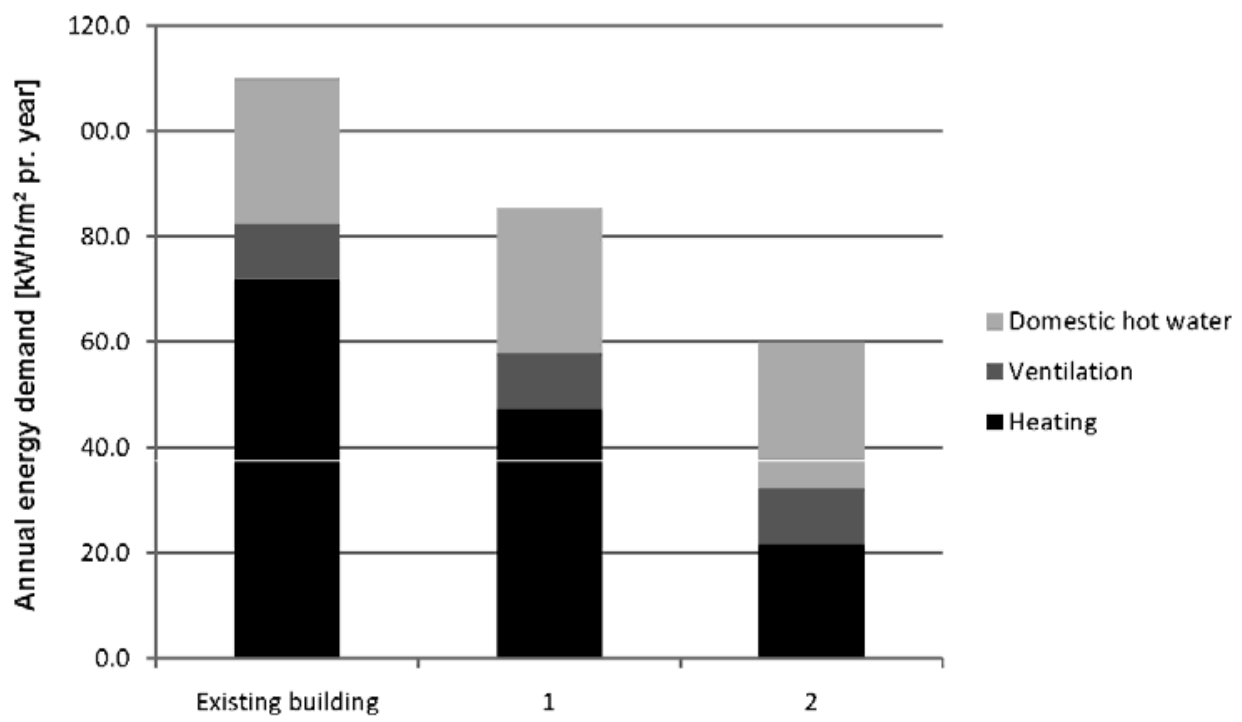

Fig. 7: Annual energy demand simulated in accordance with Danish standards for the existing building, and for Solutions 1 and 2.

The risk of overheating increases for all rooms and the total number of hours where the indoor temperature exceeds $26^{\circ} \mathrm{C}$ increases by $75 \%$ with Solution 1 and $113 \%$ with Solution 2 compared to the existing situation (Fig. 10).

The difference between the annual energy consumption in solutions 1 and 2 indicates the effect of insulating the façade on the interior side was $70,000 \mathrm{kWh}$ for the entire building. So it was investigated whether or not $70,000 \mathrm{kWh}$ can be produced by solar cells and/or solar panels instead, thus avoiding the overheating tendency caused by adding interior insulation to the façade. 


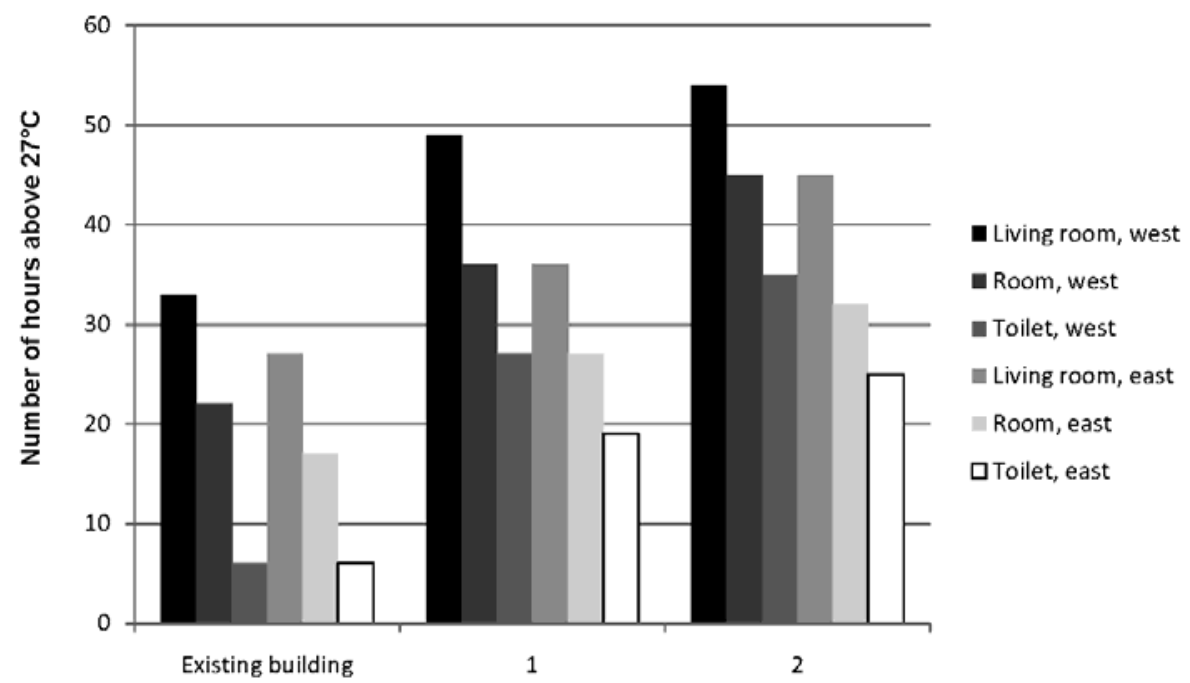

Fig. 8: Annual number of hours where the indoor temperature exceeds $26^{\circ} \mathrm{C}$ for the existing building, and for Solutions $1-2$

\subsection{Solar cells}

Since the building is listed, it is of importance that the adding of solar cells and solar heating should not disfigure the architectural expression. An investigation of the solar potential for this building shows that the south, west and east-facing roof surfaces and the south-facing gable have the greatest potential.

A dialogue with the conservation authorities suggests that the roof is less sensitive to alterations. The aim is to maintain a uniform roof surface that does not rearrange the geometry and general outline of the roof. A solution where the entire roof consists of solar cells was plausible for the authorities. This solution would be costly, but is arguably plausible since the existing roof needs replacement and it would make it easier and more economical to insulate the attic in the same process. Placing 'islands' of solar cells on the existing roof would change its appearance much more than covering the entire roof.

The roof surface is penetrated by a number of chimneys and bay windows. Some of them could be removed, but in order to preserve a history some should be left. None of the chimneys currently function as chimneys, but some have been converted into ventilation outlets. However, the preserved chimneys and bay windows will cast shadow on some of the solar cells, which will result in the need for more complicated wiring of the panels and the addition of extra bypass diodes.

In this solution, standard panels of mono-crystalline solar cells with an efficiency of $15 \%$ were chosen and placed on roof surfaces facing east, south and west. Calculations show that the 36 panels would generate $43,400 \mathrm{kWh}$ per year, taking into account the mean efficiency throughout the solar cells' service life and system efficiency.

Tab. 1: Generated effect from solar cells dependent of orientation and sum for the entire roof surface.

\begin{tabular}{|c|c|c|c|c|}
\hline Orientation of roof surface & West & South & East & Sum \\
\hline Area $\left[\mathrm{m}^{2}\right]$ & 227 & 18 & 236 & \\
\hline Solar Radiation $\left[\mathrm{kWh} / \mathrm{m}^{2}\right]$ & 947 & 1,152 & 958 & \\
\hline Effect $[\mathrm{kWh}]$ & 20,400 & 2,000 & 21,000 & $\mathbf{4 3 , 4 0 0}$ \\
\hline
\end{tabular}

The calculation in tab. 1 shows that solar cells on the roof would only generate enough energy to cover $62 \%$ of the energy reduction obtained by reducing the heating demand by means of interior façade insulation shows how electricity demand always exceeds the potential production. However, it should be noted that the price of the kilowatt hours electricity produced is higher than the kilowatt hours saved on heating. 


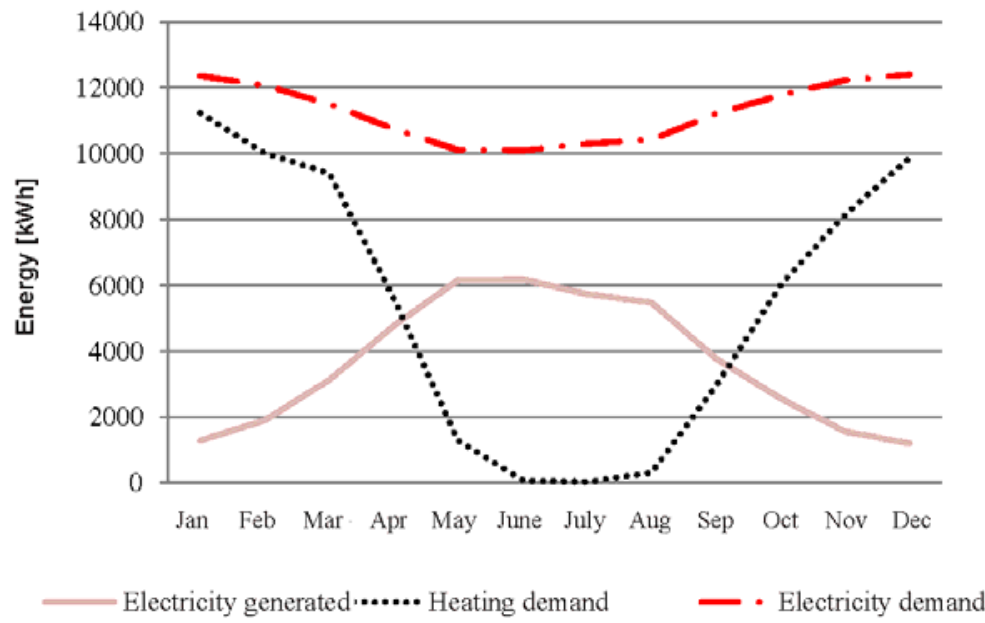

Fig. 9: Illustration of potential electricity production and the building's annual heating and electricity demand.

\subsection{Solar heating panels}

Instead of solar cells, solar heating panels could be placed on the roof to supply hot water to the building and thus substitute for interior insulation. The potential for supplying heating by means of the solar heating panels is also investigated in the following.

Tab. 2: Generated effect from solar heating panels dependent of orientation and sum for the entire roof surface.

\begin{tabular}{|c|c|c|c|c|}
\hline Orientation of roof surface & West & South & East & Sum \\
\hline Effect $[\mathrm{kWh}]$ & 44,400 & 10,200 & 44,900 & $\mathbf{9 9 , 4 0 0}$ \\
\hline
\end{tabular}

Tab. 2 shows that solar heating panels placed on the same roof surface can generate a maximum of 99,400kWh per year. The energy balance of the building was simulated in IESve and indicates the heating demand on a monthly basis, assuming that the demand for hot domestic water is the same the whole year round. The production varies with the time of the year depending on hours of sun. On this basis it is possible to compare production from the solar heating panels with the demand as shown in Fig. 10.

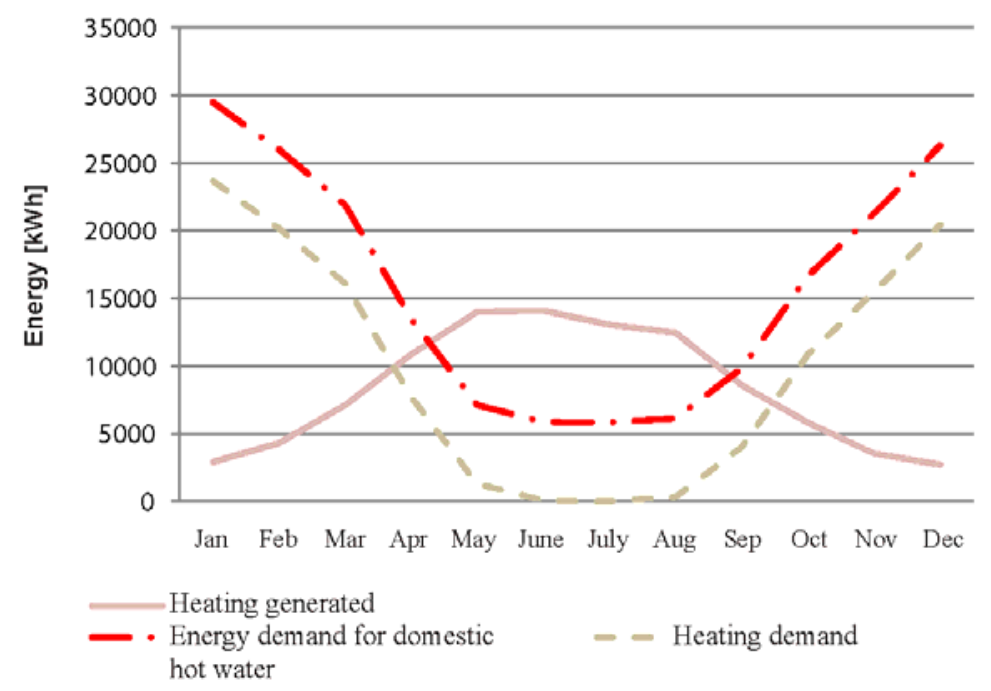

Fig. 10: Illustration of monthly distribution of potential production of heating energy via solar heating panels and the building's energy demand for heating and domestic hot water

Fig. 10 shows that there is an overproduction of heating energy from the solar panels from April to August even if the building's energy consumption of both heating and domestic hot water is taken into account. However, during the winter season the panels do not supply enough energy even to cover the demand for 
domestic hot water.

\section{Case III - Combining preservation of cultural heritage with energy renovations}

The preservation of cultural heritage is of great significance and importance to a society, but has to be balanced with the ever-increasing focus on a new common value in society: sustainability. Achieving equilibrium between these criteria and many others is a complex process with many interdependent parameters. Methods of working with evaluation based on multiple criteria are thus of major importance and these tools should adapt to the new circumstances in society. In the following, a fusion of tools to register cultural heritage and the registration of solar potential is presented. The solar gain is of major importance for the energy efficiency and effect on the indoor environment of renovation solutions as illustrated in presented cases, and therefore for sustainability.

Existing buildings have the drawbacks that their geometry is fixed and that the geometry of the urban fabric around them has changed since their construction resulting in often less advantageous use of daylight and solar heat gain. This section outlines a mapping method developed by students at the Technical University of Denmark. The mapping method supplements the well-established SAFE method (Algreen-Ussing) in giving an overview of which buildings in an urban context have the greatest renovation potential with special attention to the utilization of solar energy. The traditional SAFE method evaluates the qualities of a given building and its contribution to the cultural heritage of the neighbourhood.

The SAFE method has two levels. The first consists of a holistic analysis of context worth preserving with subgroups: dominating features, general layout of the built area and importance in relation to the context (cultural environment, landmark, landscape qualities). The second level concerns the building itself: the architectural value, value in terms of cultural heritage, originality, condition, etc.

Each category is rated from 1-9, with 1 meaning that the building should be listed, 2-3 that the building is worthy of preservation to some extent, 4-6 is a medium level and 7-9 means that no features on the building are worthy of preservation. The individual ratings collectively make up an overall rating for each building. These ratings are communicated with colour-coded maps of all major historical urban areas.(fig.11)

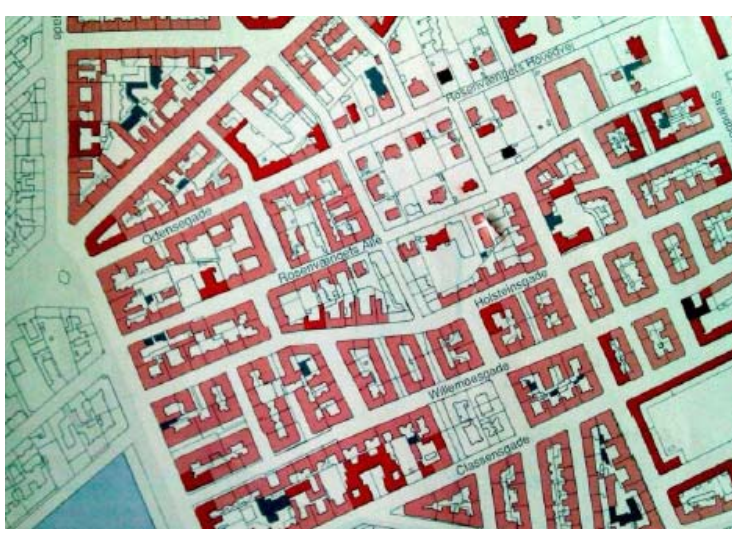

Fig. 11: Map showing the SAFE ratings for the area in Copenhagen, Denmark, that contains the building used in Case III. The dark red colour means that the building is listed

\subsection{REPO (REnovation POtential): a tool based on Multi Criteria Decision-Making (MCDM)}

When evaluating a building's renovation potential, a large number of parameters need to be taken into account. In handling this complexity, the theories and tools behind Multi-Criteria Decision-Making (MCDM) have proven to be useful.

A research group under the International Energy Agency’s Solar Heating and Cooling Task 23 investigated how MCDM could be used in the design process in the building industry (Balcomb et al). Their investigation led to the development of a software tool to facilitate the objective evaluation, prioritizing and selection of design proposals and criteria. 
To conduct a MCDM analysis, the development of 5- 8 main criteria is standard. The results from evaluating each criterion are summed up in a spider-web diagram displaying a simple-to-use graphical image (Fig. 14).
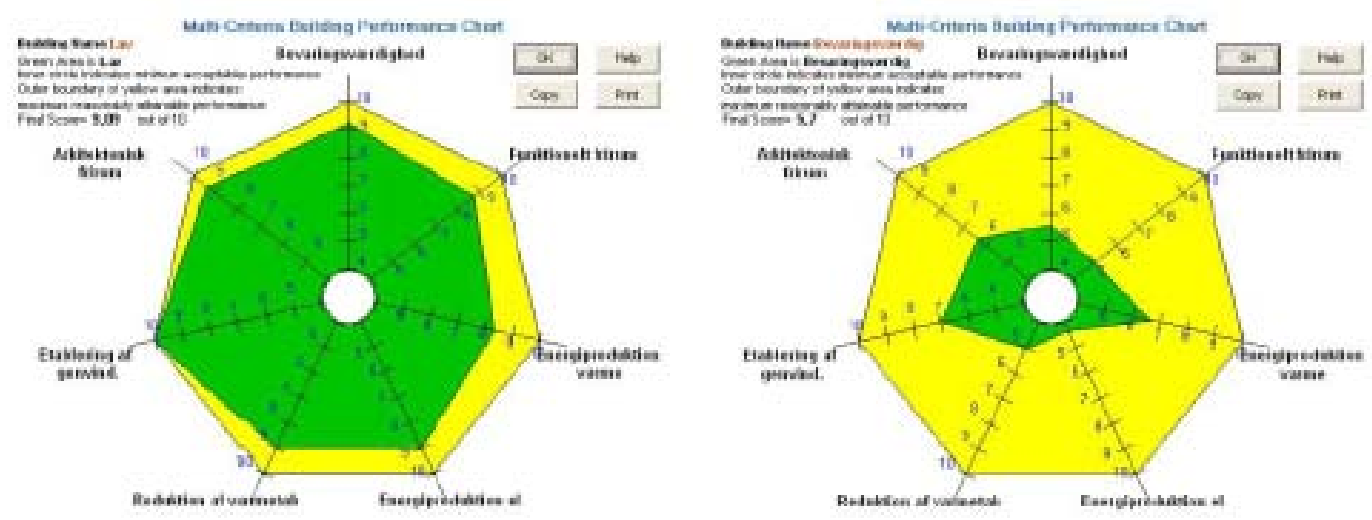

Fig. 12: Two examples showing the REPO spider-web diagram. To the left is a diagram for a building with large renovation potential due to by a low SAFE rating and thus few restrictions. The diagram to the right shows a building with many restrictions and low renovation potential.

The renovation potential of two buildings as illustrated in Fig. 12 is an overall score formed by an individual evaluation of a number of predefined criteria. The building with fewer values worth preserving has a score of 9.09 out of 10 (10 is maximum renovation potential), whereas the listed building has a score of 5.7 in respect to renovation potential.

As mentioned, the REPO analysis builds upon the SAFE method with a series of criteria:

1. Spatial organization

- To what extent can the space in the building be reorganized without causing structural problems?

- To what extent can the building be used for alternative purposes and new activities?

- To what extent is it possible to change the access to the building?

2. Establishing ventilation with heat recovery

- Is there enough space (attic or cellar)?

- To what extent can new ducts and pipework be established?

- To what extent are high indoor temperatures a problem?

3. Reduction of heat loss

- To what extent can the façades be insulated?

- To what extent is it possible to replace the windows?

- Does the conservation of mouldings and decoration prevent the insulation of façades?

4. Energy production of electricity

- Assessment of the potential for setting up PV panels. Focus is on the orientation of the building and the roof surfaces, their inclination and shadow from neighbouring buildings.

- Assessment of the potential of setting up wind turbines. Focus on the typography, wind conditions and influence on/by neighbouring buildings.

5. Energy production of heating

- Potential for passive solar heating.

- Potential for establishing solar heating panels. Focus on the orientation of the building and its roof surfaces, their inclination and shadow from neighbouring buildings.

- Can the surroundings be used for geothermal heating? Is autonomous heat production an alternative to district heating?

\subsection{Mapping solar potential}

The façade is the de facto separation between the outdoor and indoor climate and will play a very active part 
in determining the building's indoor environment and energy performance. It is to a large extent the outdoor conditions that determine how much energy has to be used to obtain a good indoor environment and here the mapping of the solar potential is of great importance. The above-mentioned criteria for the REPO analysis address these issues. In the following, the solar potential of a residential block of flats originally constructed in 1870 is analysed.

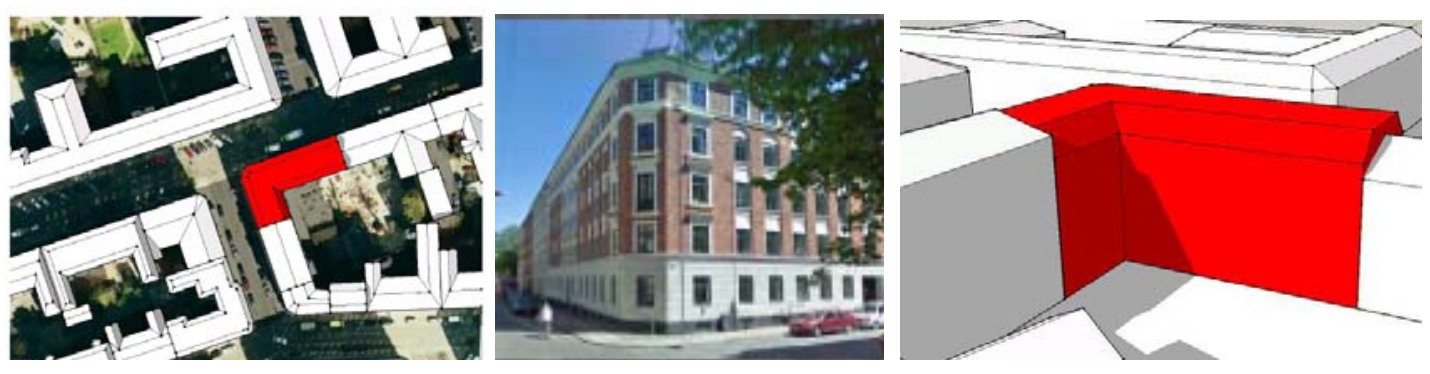

Fig. 13: Map showing the location of the case building in its context (to the left) and picture of the existing building showing the façades towards the street facing north and west

From the analysis, it can be concluded that the insolation is highest on the south-facing façade and roof surface. Because the building is a corner building, facing a broad crossing, neighbouring buildings do not cause much shadow (fig. 13). After noon the west-facing part of the block casts a shadow on the south façade facing the courtyard. The solar potential is thus greatest on the upper eastern part of the south-facing façade.

Before noon, the east-facing façade and its roof receive sun, while the west-facing façade only receives sun during the evening. At midday, the almost horizontal roof of the typical Copenhagen block has a large solar potential.

Such a simple mapping and analysis of the solar potential is very beneficial when designing renovation solutions for either a single block or an area as a whole. On this basis, techniques and solutions can be tailored to the specific buildings and in larger scale renovation projects result in a collective of buildings functioning together. Thus, based on the REPO analysis, renovation proposals for the building described above very early in the design process included PV-panels on the rear, south-facing roof and a Canadian sun wall on the part of the back yard façade with the largest solar potential. This proposal could be accepted by the local authority because the street façade would remain unaltered.

Interviews with preservation authorities in Denmark, point to a tendency to allow considerable design freedom for façades facing the rear yard. Another tendency is that the authorities are mainly preoccupied with the preservation of the general character of a historical neighbourhood. A mapping of both cultural heritage and solar potential together would point to which listed buildings could be 'sacrificed' in order to comply with demands for sustainable solutions.

\section{Conclusion}

It is important to increase the motivation of investors and public authorities with regard to energy renovation. In this respect, the design strategies applied to the process should be carefully considered. Design strategies that lead to an automatic choice of a full cladding with insulation and new windows risk creating design proposals that have poor aesthetic qualities and add no extra qualities apart from a reduction in heating demand. Furthermore, the results of this paper question whether full cladding with insulation automatically leads to the best solution if indoor environmental quality is considered alongside energy reduction.

A number of historical buildings have a large potential for energy storage due to thermal mass with high heat capacity. This embodied energy can be addressed and used to the advantage of energy reduction and a good indoor climate, but interior insulation risks neutralizing this potential. The carefully considered positioning of insulation at the most efficient locations in a building is a precondition for expanding the scope of energy renovation. 
Information on the original building's indoor climate is of importance. A starting point where the original building has severe problems with overheating or inadequate daylight focuses the design process and leads to design solutions that will not only reduce energy demand but also give an experience for users of having gained extra qualities.

To expand the scope of design proposals for energy renovation, it is important to make an advanced indoor climate and energy simulation model at the beginning of the design process. The information gained from this model will suggest design potentials unique for the building in question. Since the geometry and orientation of the building in question are fixed from the beginning, the advanced simulations early in the design process represent an efficient method. These simulations increase the space of solutions and thus give space for a wider scope of proposals that can match the demand for preservation of the cultural heritage and architectural content of a building.

Society will have to value sustainability on an equal level with cultural heritage and listed buildings have to be addressed as well. The mapping of a building's solar potential in its specific urban context, and thus its embodied capacity for producing energy, is an important benchmark that could be used to point to less publicly exposed parts of the building with high solar potential, which could be redesigned without loss of cultural heritage. For instance the roofs and façades facing the back yards of the traditional European urban block structure hold such potential.

The integration of energy-producing elements in energy renovation projects should be considered as part of a holistic design solution. The careful selection of energy-producing elements is part of a technically and scientifically informed design process. In energy renovation projects, each building is unique and the energyproducing elements adequate for one building might not suit a neighbouring building. The architectural integration of such elements is challenging, so finding the places on the building that allow the most freedom for design is vital. Combining solar potential mapping with mapping of cultural heritage can reveal such areas on the building.

Taking care to analyse and utilize the potentials of the existing building and designing from that point of departure will reduce the risk of problem shifting. A holistic approach informed by simulations already at the beginning is a prerequisite for design renovation solutions that can enhance the building's qualities and reduce energy demand. A larger design platform for carrying out energy renovation is desirable in order to motivate and increase the number of energy renovation projects in the future.

\section{References}

Byg-Erfa Foundation, 2009, Document \# 310910 29, Denmark

Danish Building Research Institute, 2006, BSIM, Integrated Software for Thermal Analysis of Buildings and Installations, Denmark

CIBSE , Guide A, Environmental Design.

EBST. Bygningsreglement for erhvervs- og etagebyggeri, National Agency for Enterprise and Construction, Copenhagen, Denmark, 2010.

Balcomb, D.,Andresen, I., Hestnes, A.G.,2002.Multi-CriteriaDecision-Making MCDM-2, Colorado

Algreen-Ussing,G., 1995. Survey of Architectural Value in the Environment, Denmark 
